\title{
SEDIMENTOLOGY AND PALAEOENVIRONMENTAL RECONSTRUCTION OF AG-1 CORE OF AYVALIK REGION, NW TURKEY
}

\author{
Nikolaou K. ${ }^{1}$, Alysandratou A. ${ }^{1}$, Karanika K. ${ }^{1}$, Kaya Y. ${ }^{2}$, Inaner H. ${ }^{3}$, \\ Christanis K. ${ }^{1}$, Iliopoulos G. ${ }^{1}$ and Avramidis P. ${ }^{1}$ \\ ${ }^{1}$ University of Patras, Department of Geology, 26500, Patras Greece \\ ${ }^{2}$ Geologist at Altinova Municipality \\ ${ }^{3}$ Dokul Eylul University, Department of Geological Engineering, TR-35160, Izmir, Turkey, \\ nikolaoukost@upatras.gr,geo11002@upnet.gr, konstantinapat@gmail.com, \\ hulya.inaner@deu.edu.tr, christan@upatras.gr,iliopoulosg@upatras.gr,p.avramidis@upatras.gr
}

\begin{abstract}
This study presents sedimentological and palaeontological data retrieved from a coastal lagoon near Ayvalik in NW Turkey. The objective of this study is to interpret the depositional environments and reconstruct the evolution of the study area during the late Holocene. 42 sediment samples have been retrieved from a $13 \mathrm{~m}$ core. Sedimentological analyses such as grain size analysis, moment measures of mean, sorting, skewness and kurtosis, definition of total organic carbon (T.O.C.), total nitrogen (T.N.), colour and $\mathrm{CaCO}_{3}(\%)$ were employed. Moreover, macro and microfossils were collected to reconstruct the depositional environments. The palaeoenvironmental - palaeoecological analyses indicated a closed shallow shelf environment (around 4000 to 2400 yr BP) that gradually turned into a leaky lagoon (around 2400 yr BP to present).

Keywords: deposition environment, sedimentology, paleoecology, geochemistry.
\end{abstract}

\section{Introduction}

During Holocene several changes took place in the Mediterranean Sea. Climatic changes, eustatism and tectonism are responsible for the geomorphological modifications of the coastal areas. During the last glacial maximum (21-17ka BP) sea level was 115-120 meters below present level. The rising of the sea level had been relatively slow but accelerated from 12-6ka years BP, mostly from the melting of polar ice sheets (Fairbanks, 1989). The rising sea level during the Holocene epoch reached its present levels around 6ka BP. More specifically, Lambeck, (1995) and Lambeck and Purcell, (2005) estimated that sea level at 6ka BP was 6 meters lower in N. Aegean Sea and 2 meters in N. Greece than its present level.

Coastal areas are of great significance in geology as they are affected by both the marine and the continental realms. Such continuously changing areas include coastal lagoons and ecosystems which are very important for coastal geology and aquatic ecology. Coastal evolution depends on the local geological and geomorphological conditions, climate, tectonism and the relative sea level changes.

Coastal lagoons are areas with shallow brackish waters, separated from the open sea with sandy or shingly barriers (Kjerfve, 1994; Bird, 2008). These sensitive ecosystems are hosting unique types of fauna and flora adjusted to the fluctuating annual salinity. Being on the border of two realms they 
are vulnerable to eustatic and tectonic changes, and recently to human intervention. Total organic carbon (TOC) and total nitrogen (TN) are important sediment characteristics, used to discriminate the origin of the organic matter (marine-terrestrial), defining the depositional conditions, the contamination factors and the productivity indicators (Caroll et al., 2003; Schaanning, 1994). Grain size distribution and geochemical data such as measurements of total organic carbon (TOC), total nitrogen (TN) and a variety of elements, provide significant information on the sediments and the respective depositional environments.

In the present study, data from a $13 \mathrm{~m}$ core (AG-1) from a Tuz Gölü lagoon, $7.94 \mathrm{~km}$ SW from Ayvalik in NW Turkey are presented. Spatial sedimentological and geochemical data have been calculated from 42 samples. In addition, macro and micro faunal analysis of subfossils and radiocarbon dating analysis were performed in order to reconstruct the evolution and the depositional environments of the studied area.

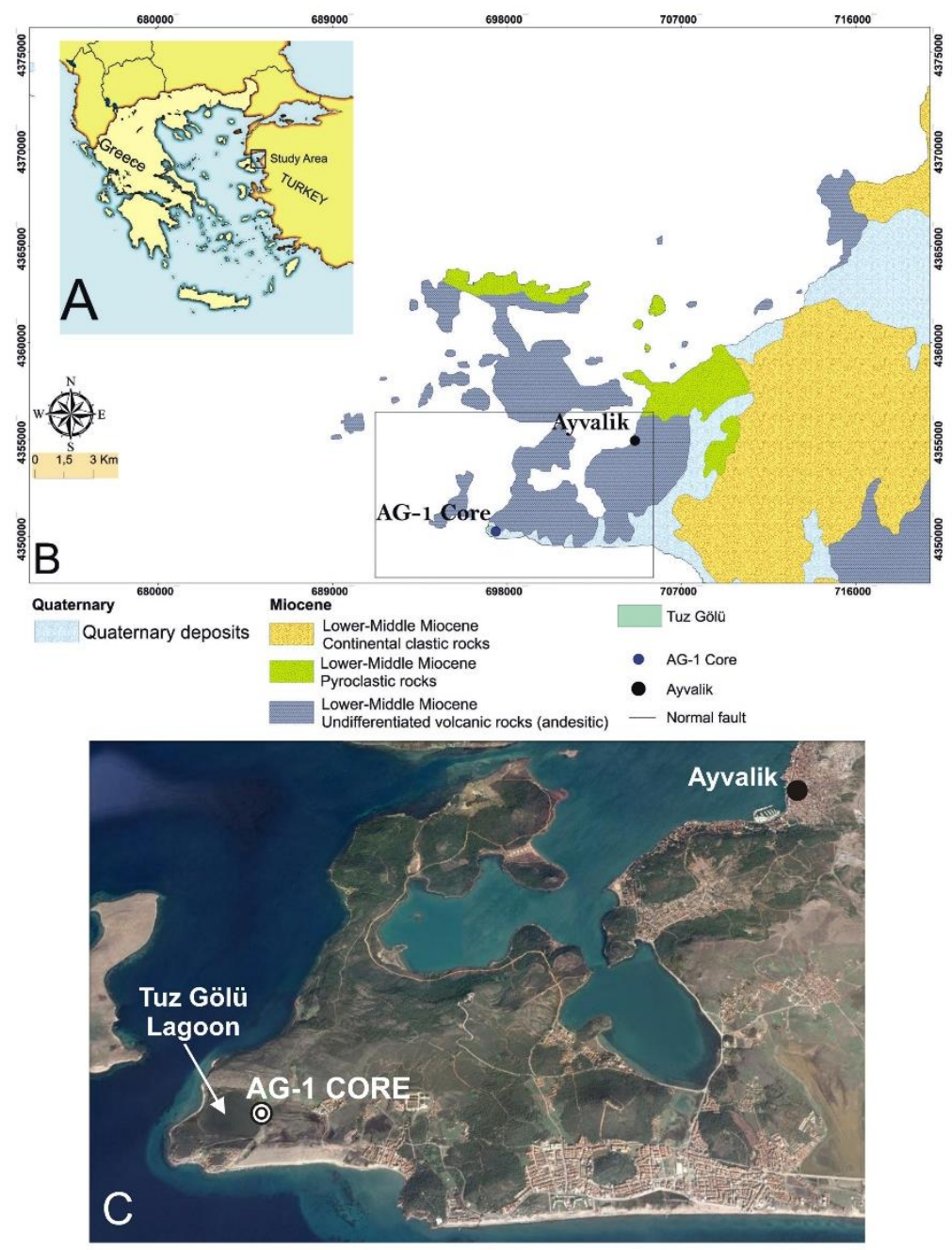

Figure 1 - (A) General map of the Aegean with the study area in the inserted box, (B) simplified geological map of Ayvalik area modified from the respective geological map of the Balikesir Province of Turkey (Senel, 2002) and (C) the actual location of the AG-1 core. 


\section{Regional setting}

Ayvalik is a town located on the western coast of Turkey (Figure 1A, B and C), a district in the Balikesir province which is considered as one of the most active tectonic regions of Turkey.

5.1. The most striking feature of this region is the coastal morphology that consists of peninsulas and of numerous coves and bays. The area has been affected by eustatic and tectonic processes forming sandy beaches, cliffs, dunes, coastal marshes, crescent shaped beaches, lagoons, islands and peninsulas (Kayan, 1999).

The volcanic and sedimentary rocks that compose the geological formations of the wider Balikesir Province area were formed between the Palaeozoic era and the Quaternary period (Senel, 2002). The NW part of this area is covered by Triassic granitoids and Triassic clastic and carbonate rocks, whereas, upper Palaeozoic schists can be found in the NE part. Lower to middle Miocene undifferentiated volcanic rocks (andesitic) extend from the west to the south, surrounding granitoid masses located to the east of the study area. North and East of Ayvalik, lower-middle Miocene continental clastic rocks and pyroclastic rocks can be found. Further eastwards, patchy outcrops of Quaternary basalts appear (Figure 1B). Practically the whole coastal area surrounding Ayvalik is composed of Quaternary deposits and lower to middle Miocene undifferentiated volcanic rocks (andesitic) (Senel, 2002).

\section{Materials and Methods}

The core AG-1 was drilled in the coastal lagoon Tuz Gölü SW of Ayvalik, $\left(39^{\circ} 16.587^{\prime} \mathrm{N}\right.$ and $26^{\circ} 37.138^{\prime} \mathrm{E}$ ) (Figure 1). The drilling equipment was a rotary wagon type drill (GEO 205) with a driling rig of Comacchio Company, with a single tube core barrel with tungsten carbide bit and 101 $\mathrm{mm}$ diameter. The total depth of the borehole was $13 \mathrm{~m}$.

The AG-1 core was then carried to the Sedimentology laboratory of the Department of Geology in the University of Patras. The core was processed and 42 samples were collected. Standard sedimentological analyses were carried out such as grain size, moment measure of mean values, sorting, skewness and kurtosis. Grain size analysis was held out using a sequence of mesh sieves and Malvern Mastersizer 2000 Hydro while moment measures and statistical parameters were calculated using GRADISTAT V.4 (Blott and Pye, 2001) and sediments were characterised based on Folk's, (1974) nomenclature. Colours were defined using a Minolta CM-2002 hand-held spectrophotometer based on Munsell's colour chart.

Total organic carbon (T.O.C.) was defined using the wet oxidation-titration technique (Gaudette $e t$ al., 1974), while total nitrogen (T.N.) using an elemental analyser (CHN Ratios Elemental Analyzer). $\mathrm{CaCO}_{3}(\%)$ was calculated using a FOG II/Digital hand-held soil calcimeter Version 2/2014 (BD INVENTIONS). $\mathrm{CaCO}_{3}(\%)$ was calculated using a FOG II/Digital hand-held soil calcimeter Version 2/2014 (BD INVENTIONS). CaCO3 (\%) calculation was based on measuring emitted CO2 a modified method by Muller and Gastner, (1971) and Jones and Kaiteris, (1983).

Forty two dried sediment samples of approximately $25 \mathrm{~g}$ were collected for micro and macrofaunal analysis. The sediments were washed with tap water through $0.5 \mathrm{~mm}$ and $0,063 \mathrm{~mm}$ mesh sieves. The processed sediments were dried overnight in the oven $\left(40^{\circ} \mathrm{C}\right)$ and macro and microfossils were collected under a Zeiss 475002 stereoscope. Sieved sediment was split and up to 300 microfossils were collected. Using all data, a composite stratigraphic column was created (Figure 2). Radiocarbon analysis was carried out in Beta Analytics Labs. Radiocarbon age was determined on three samples of intact mollusc shells from three different layers and results such as Conventional Radiocarbon Age and Two-Sigma calendar calibration were taken. 


\section{Results}

\subsection{Stratigraphy and grain size distribution, Total organic carbon (T.O.C.), total nitrogen (T.N.) and $\mathrm{CaCO}_{3}$}

Apart from the first two meters consisting of the Andesitic bedrock (13 - 10.9 m), the AG1 core has been divided into 5 sedimentological units based on grain size distribution, sediment characteristics, colour, moment measurements, $\mathrm{TOC}, \mathrm{TN}$ and $\mathrm{CaCO}_{3}$ content (Figure 2): Unit 1 (10.90-9.00 m), Unit 2 (9.00 - $5.80 \mathrm{~m})$, Unit $3(5.80-2.30 \mathrm{~m})$, Unit $4(2.30-1.50 \mathrm{~m})$ and Unit $5(1.50-0.00 \mathrm{~m})$.
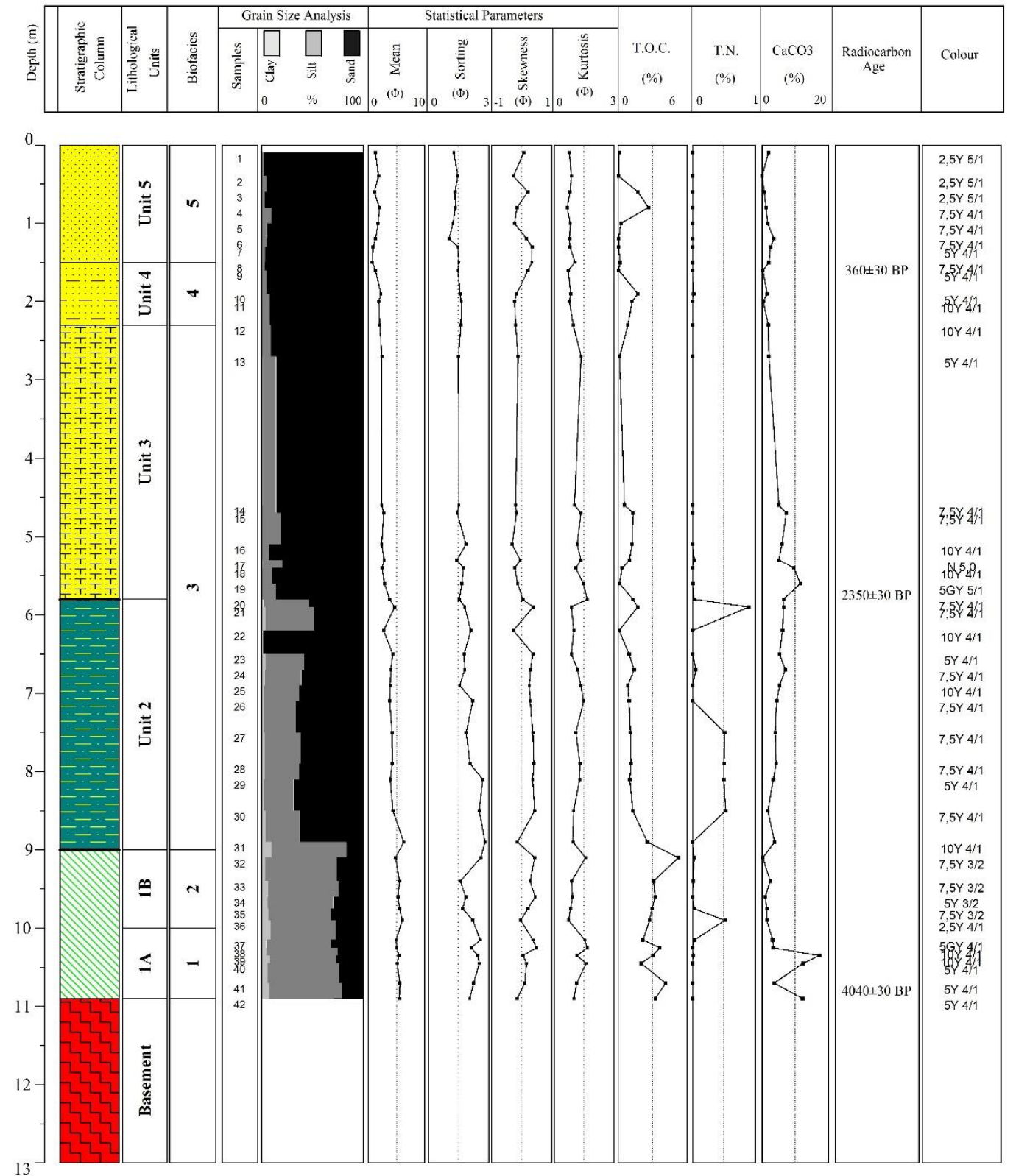

Figure 2 - Stratigraphic column showing grain size distribution, geochemical and radiocarbon dating results. 
Unit 1 (10.90-9.00 m) refers to the lower unit of the core (Figure 2). In this unit shell fragments and plant remains are very abundant. Grain size ranged from coarse silt to very coarse silt while sediment colour ranged from dark gray to dark greenish gray. The unit consists of poorly sorted to very poorly sorted grain distribution $(\sigma 1.50-2.64)$ while mean values ranged from $4.83 \Phi$ to $5.97 \Phi$. Skewness ranged from $-0.14 \Phi$ to $0.49 \Phi$ defining a coarsely skewed to very fine skewed grain distribution. Values of kurtosis ranged from $0.73 \Phi-1.67 \Phi$ indicating a platykurtic to very leptokurtic distribution. T.O.C. values in this unit of the core ranged from 1.98-5.21\% with an average of $3.2 \%$, while values of T.N. ranged from 0.0-0.51\%. In this unit $\mathrm{CaCO}_{3}$ percentage ranged from $0.3-17.3 \%$. Sedimentary Unit 1 has been further divided into subunit $1 \mathrm{~A}(10.90-10.00 \mathrm{~m})$ and subunit $1 \mathrm{~B}(10.00-9.00 \mathrm{~m})$ based on the changing colour, which becomes darker, and a distinct increase in T.O.C. values (greater than $3 \%$, Figure 2).

Unit $2(9.00-5.80 \mathrm{~m})$ contains several macro and micro fossil fragments, mica and plant remains (probably Posidonia) (Figure 2). This is a transitional sedimentological section to a segment unit that is rich in plant debris throughout its extent. Sediment colour ranged from dark gray to dark greenish gray. The unit consists of moderately sorted to very poorly sorted grain distribution $(\sigma 0.99$ 2.38 ), while mean values range between $2.68 \Phi$ and $6.25 \Phi$. Skewness propose a coarsely skewed to very fine skewed grain distribution $(-0.25-0.44 \Phi)$. Values of kurtosis define a mesokurtic to very

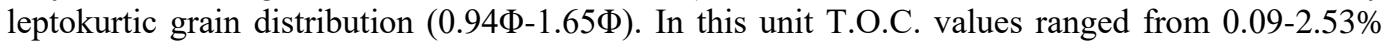
with an average of $1.17 \%$, while values of T.N. ranged from $0.0-0.9 \% . \mathrm{CaCO}_{3}$ percentage ranged from $1.8-7.0 \%$ with an average value of $4.73 \%$.

Unit $3(5.00-2.80 \mathrm{~m})$ is characterized by medium to fine grained sand (Figure 2). It should be noted that a quantity of sediment was partially lost during the coring procedure between $2.70-4.60 \mathrm{~m}$ (core recovery $60 \%$ ), so detailed data from this depth cannot be presented. Micas are very abundant and sediment colour ranged from dark gray to dark greenish gray. In this unit shell fragments are also abundant. The unit shows poor sorting $(\sigma$ 1.37-1.84) while mean values ranged between $1.99 \Phi$ and $2.82 \Phi$. Values of skewness ranged from $-0.21 \Phi$ to $-0.04 \Phi$ and define a coarse skewed to symmetrical grain distribution. Values of kurtosis defined a mesokurtic to leptokurtic grain distribution (0.93Ф$1.45 \Phi)$. In this unit T.O.C. values ranged from $0.12-1.29 \%$ with an average of $0.74 \%$, while values of T.N. ranged from $0.0-0.02 \% . \mathrm{CaCO}_{3}$ percentage ranged from $2.1-11.5 \%$ with an average value of $6.65 \%$.

Unit $4(2.30-1.50 \mathrm{~m})$ grain size ranged from fine to coarse grained sand, while the percentage of clay does not exceed $0.3 \%$ (Figure 2). In this unit shell fragments are abundant and colour ranged from dark gray to dark greenish gray. The unit presents poor sorting $(\sigma$ 1.36-1.78), while mean values ranged between $0.66 \Phi$ and $2.19 \Phi$.Values of skewness ranged from $-0.23 \Phi$ to $0.38 \Phi$ and define a coarse skewed to very fine skewed grain distribution. Values of kurtosis define a platykurtic to mesokurtic grain distribution $(0.76 \Phi-1.05 \Phi)$. T.O.C. values ranged from $0.03-1.71 \%$ with an average of $0.95 \%$, while values of T.N. ranged from $0-0.03 \% . \mathrm{CaCO}_{3}$ percentage ranged from 0.3 $1.9 \%$ with an average value of $1.05 \%$.

Unit 5 (1.50-0.00 m) refers to the upper part of the core (Figure 2). The grain size of this unit ranges from coarse to medium sand with the percentage of clay not exceeding $0.45 \%$. Shell fragments are less abundant and colour ranged between gray and dark gray. The unit consists of poorly sorted sediments $(\sigma$ 1.37-1.93), while mean values ranged between $0.79 \Phi$ and $1.76 \Phi$. Values of skewness were calculated from $-0.22 \Phi$ to $0.37 \Phi$ and defined a very fine skewed to coarse skewed grain distribution. Values of kurtosis defined a platykurtic grain distribution $(0.72 \Phi-0.88 \Phi)$. In this unit T.O.C. values ranged from $0.03-2.63 \%$ with an average of $0.62 \%$, while values of T.N. are zero in the whole unit. $\mathrm{CaCO}_{3}$ percentage ranged from $0.0-3.6 \%$ with an average value of $1.74 \%$. 


\subsection{Radiocarbon dating}

The chronological framework of this study was based on linear regression of three radiocarbon datings from three individual Cerastoderma valves. The results of the radiocarbon datings from Beta Analytics Lab in Miami, U.S.A. are presented in table 1.

Based on conventional radiocarbon age results and using OxCal software (Bronk Ramsey, 2009) the age depth curve was drawn and the age of each sedimentary unit was interpolated and estimated. The age of the first sedimentological unit ranged between around 4040-3460 $\pm 30 \mathrm{BP}$, of the second from around 3460-2402 $\pm 30 \mathrm{BP}$, of the third ranged from around $2402-740 \pm 30 \mathrm{BP}$, of the fourth between around 740-360 $\pm 30 \mathrm{BP}$ and finally of the fifth from around 360-0 $\pm 30 \mathrm{BP}$.

Table 1- Radiocarbon results from Beta Analytic Lab, Miami, U.S.A.

\begin{tabular}{|c|c|c|c|c|c|c|}
\hline Sample & $\begin{array}{c}\text { Depth } \\
(\mathbf{m})\end{array}$ & $\begin{array}{c}\text { Laboratory } \\
\text { reference }\end{array}$ & $\begin{array}{c}\text { Material } \\
\text { dated }\end{array}$ & $\begin{array}{c}\text { Conventional } \\
\text { years }{ }^{14} \mathbf{C} \\
\text { (years BP) }\end{array}$ & $\begin{array}{c}\text { Calibrated } \\
\text { years BP } \\
\mathbf{1 \sigma}\end{array}$ & $\begin{array}{c}\text { Calibrated } \\
\text { years BP } \\
\mathbf{2 \sigma}\end{array}$ \\
\hline R1 & 1.50 & Beta 399486 & Shell & $360 \pm 30$ & - & - \\
\hline R2 & 5.65 & Beta 399487 & Shell & $2350 \pm 30$ & $1860-1730$ & $1905-1685$ \\
\hline R3 & 10.80 & Beta 399489 & Shell & $4040 \pm 30$ & $3920-3810$ & $3980-3715$ \\
\hline
\end{tabular}

\subsection{Macro and microfaunal analysis}

The collected macro- and microfaunal remains provided taxa that belong to six different phyla (mo lluscs, arthropods, foraminifera, bryozoans, serpulids and echinoderms). More specifically, 21 biva lve, 45 gastropod, 2 scaphopod, 16 ostracod and 27 foraminifera species have been determined as well as representatives of bryozoan colonies, sea urchin spines and plates, serpulid tubes and decap od shell fragments (Figure 3). The dominant taxa in the sampled assemblages are the gastropod Bit ium reticulatum, and the foraminifera Ammonia beccarii, Ammonia tepida, Elphidium crispum and Elphidium macellum. In addition macrophytic remains, belonging to Posidonia oceanica, have be en recognised in the lower part of the core. Based on the distribution of the subfossil findings along the core, five biofacies have been identified.

At the lower part of the core, biofacies 1 spreads from 10.9-10.0 m. It is characterised by the dominance of $B$. reticulatum and the significant contribution of shallow shelf taxa such as the gastropod taxa Pyramidellidae (Turbonilla lactea, Eulimella cf. acicula, Odostomia spp. and Parthenina cf. monozona), Pusillina marginata, Rissoa membranacea, Trochidae (mainly Jujubinus striatus and Gibbula spp.), Calliostoma conulus, Tricolia pullus, Cerithiopsis sp., Granulina marginata, Mysia undata, the bivalves Nucula nucleus, Parvicardium spp., Parvicardium pinnulatum, the foraminifera Ammonia beccarii, Ammonia tepida, Elphidium crispum, Elphidium macellum, Haynesina germanica, Lobatula lobatula, Rosalina sp., and the ostracods Loxoconcha rhomboidea, Semicytherura acuticostata, Carinocythereis carinata and Loxoconcha elliptica (Figure 3). The presence of Posidonia oceanica plant remains is very distinct. The number of species in this unit is 63.

Biofacies $2(10.0-9.0 \mathrm{~m})$ is characterised by the absence of macro- and microfaunal remains hence it is considered as barren. Nevertheless, $P$. oceanica remains are quite abundant.

The next one, biofacies 3 ranges from 9.0-2.3 m depth. Most shallow shelf taxa that had been identified in biofacies 1 are maintained in the assemblages. Concerning the macrofossils $B$. reticulatum dominates, followed by the foraminifera A. beccarii, A. tepida, E. crispum and $E$. macellum. P. marginata, $H$. germanica, the molluscs Trochidae and P. exiguum, and Loxoconha species are also contributing in the assemblages (Figure 3 ). Some taxa such as the molluscs $P$. 
pinnulatum, Odostomia spp., C. conulus, M. undata and Cerithiopsis sp. are lost and are replaced by other taxa such as the foraminifera Peneroplis planatus in significant numbers, Planorbulina mediterranensis, Cibicides spp., Milliolidae, the ostracods $N$. crenulata, C. torosa f. litoralis, Xestoleberis decipiens, the gastropods Hydrobia acuta, Potamides conicus, Retusa leptoeneilema, the bivalves Musculista perfragilis, Loripes lucinalis, Abra sp., Petricola lithophaga, the scaphopod Pulsellum lofotense, Bryozoa, Serpulidae, decapod (crabs) and the distinct presence of the gastropod Vermetes triquetrus (Figure 3). The lower part of the unit is also characterised by the distinctive presence of $P$. oceanica remains. The species number in this unit is 91 .

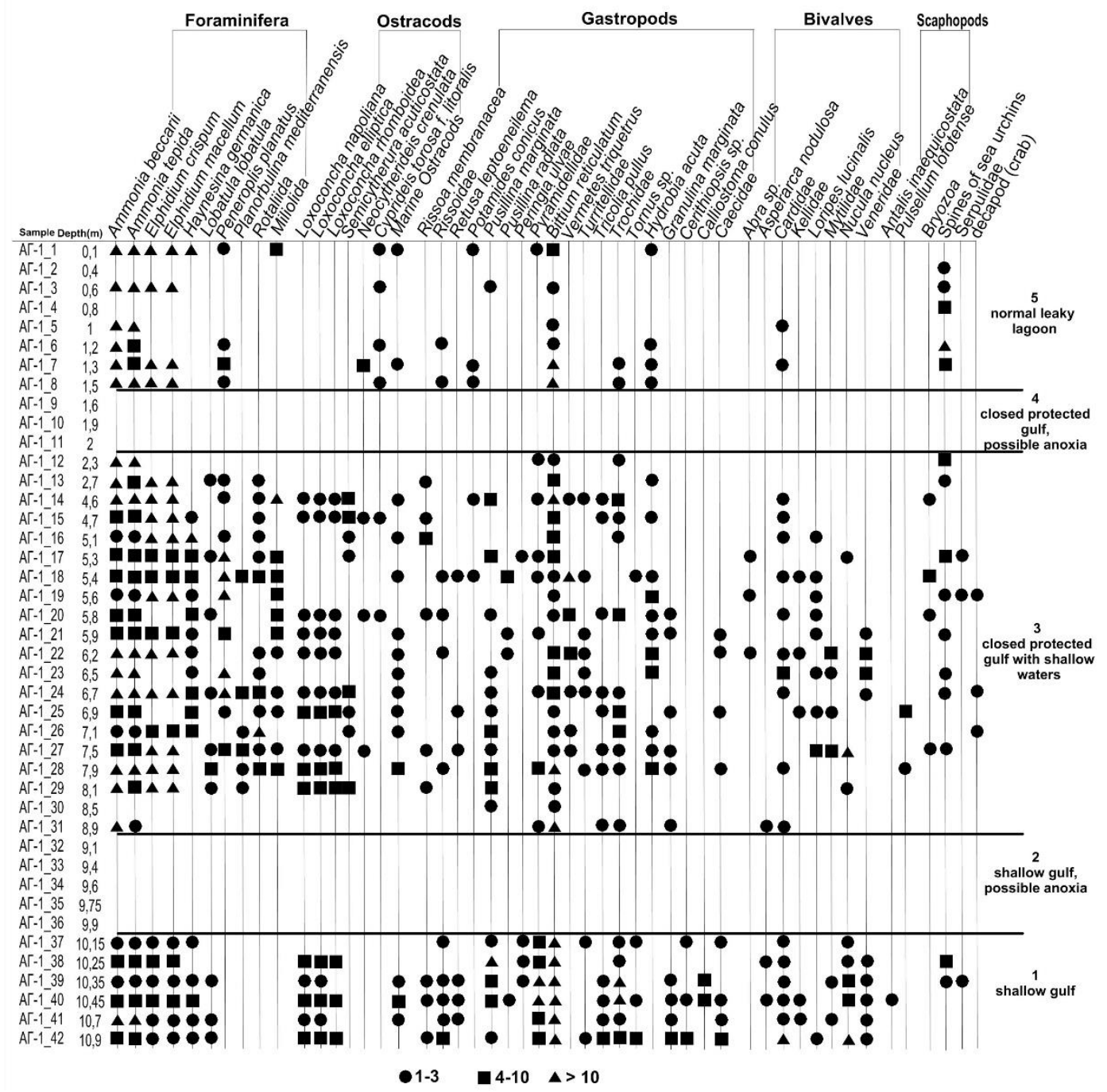

Figure 3 - Macro and microfaunal contents of the studied samples from core AG-1.

From 2.3 - $1.5 \mathrm{~m}$ subfossils are absent, thus the sediments of biofacies 4 can also be considered as barren as well.

Finally, biofacies 5, ranging from $1.5-0 \mathrm{~m}$, is also dominated by $B$. reticulatum, whereas the foraminifera Ammonia beccarii, Ammonia tepida, Elphidium crispum and Elphidium macellum are present in considerable numbers (Figure 3). Typical brackish taxa such as the ostracods Cyprideis torosa f. litoralis, Neocytherideis crenulata, the gastropod Hydrobia acuta and the foraminifer $H$. 
germanica are present in small numbers. In addition the increased number of sea urchin spines is notable. The species number in this Unit drops to 24.

\section{Discussion-Conclusion}

Based on the correlation of Figure 2 and Figure 3, it can be concluded that sedimentary Subunit 1A corresponds with biofacies 1, whereas, Subunit 1B to biofacies 2 . Similarly sedimentary Units 2 and 3 are both parts of biofacies 3, while sedimentary Units 4 and 5 can be referred to biofacies 4 and 5 respectively.

The assemblages in biofacies 1, 3 and 5 are characterised by the dominance of shallow shelf, subtidal and intertidal taxa, of which several can be characterised as epiphytal and soft bottom, nutrient rich dwellers. In particular, in biofacies $1(10.9-10.0 \mathrm{~m})$ the presence of shallow shelf taxa indicate a shallow infralittoral environment (Bakir et al., 2012; Fishelson, 2000; Murray, 2006; Frenzel et al., 2010; Perçin-Paçal, 2015). The significant contribution of $P$. marginata, $R$. membranacea, T. lactea, E. cf. acicula, Odostomia spp., N. nucleus, P. exiguum suggest that the water depth did not exceed $10 \mathrm{~m}$ although shallower water dwellers such as T. pullus are present (Bakir et al., 2012). In addition the substrate consisted of soft bottom muddy sands rich in nutrients being in agreement with the considerable numbers of Ammonia and Elphidium taxa (Murray, 2006). This can be also shown from the grain size that ranged from coarse to very coarse silt while the values of T.N. reach the second higher value of the whole core measurements. The significant numbers of the dominant epiphytic gastropod B. reticulatum and the considerable numbers of the phytal ostracod taxa L. elliptica and $L$. rhomboidea, as well as the presence of the foraminifer $L$. lobatula verify the presence of shallow water algae and in particular of sparse P. oceanica meadows (Bakir et al., 2012; Frenzel et al., 2010) as it is also shown by the plant remains in the studied assemblages. Hence, the increased presence of $P$. oceanica remains evinces significant meadow density and consequently shallow waters where organic debris accumulated over centuries (Hemminga and Duarte 2000), and oxygenated waters with a narrow range of salinity, from 33\% to 39\%o (Díaz-Almela and Duarte, 2008; FernándezTorquemada and Sánchez-Lizaso, 2005). L. rhomboidea, S. acuticostata and C. carinata also point towards euhaline waters, although L. elliptica and A. tepida mark at least occasionally polyhaline conditions (Frenzel et al., 2010; Murray, 2006). The environment could represent a gulf with good connection to the open sea with occasional fresh water supply.

The total absence of macro- and microfaunal remains in biofacies 2 (10.0-9.0 $\mathrm{m})$, possibly is indicative of inhospitable conditions for living organisms due to severe anoxia that did not allow even low oxygen dwellers to survive, as the area probably turned into a closed gulf with no good connection with the sea. This anoxical event can be correlated well with the significant increase of T.O.C. percentage reaching here it's maximum values. Nevertheless, the presence of numerous plant remains (most likely of Posidonia oceanica) which are generally indicative of good environmental conditions are not consistent with oxygen depleted environments, thus, their dense concentrations could be related to anaerobic decomposition of plant material, eutrophication, and/or increased sulphide concentration (Marbà et al., 2006). Possibly, suitable conditions for the development of dense meadows persisted originally in biophacies 2 , nevertheless, abrupt changes as described above caused oxygen deprivation affecting benthic communities.

In biofacies $3(9.0-2.3 \mathrm{~m})$ a significant increase in the species number is observed, 91 species have been recorded compared to 63 from biofacies 1 . The notable presence of taxa such as $V$. triquetrus, P. lithophaga, H. acuta, T. pullus, C. torosa f. litoralis, L. elliptica, Bryozoa and serpulidae indicate very shallow protected waters of the mediolittoral zone with a depth less than $2 \mathrm{~m}$ (Bakir et al., 2012; Fishelson, 2000; Frenzel et al., 2010). The increased presence of several typical epiphytic taxa, such as the gastropods $B$. reticulatum, $M$. perfragilis, the phytal ostracod taxa $L$. elliptica and $L$. rhomboidea, the permanently attached foraminifera L. lobatula and P. mediterranensis, as well as the motile grazing $P$. planatus and Rosalina sp. indicate the presence of shallow waters with $P$. oceanica meadows, at least at the lower part of this biofacies (Murray, 2006; Bakir et al., 2012; 
Frenzel et al., 2010). The presence of P. exiguum, L. lucinalis, Ammonia, Elphidium and Miliolid taxa suggest soft bottom substrates (Murray, 2006; Bakir et al., 2012). In addition the presence of $P$. lithophaga shows towards the presence, in close proximity, of a hard calcareous substratum habitat suitable for this boring endobiont living in shallow waters (Kovalyova, 2015), hence its valves were transported. The increased presence of sea urchin spines in the upper part of this biophacies as well as in biophacies 5 are possibly indicative of increased populations of the grazing Mediterranean taxon Paracentrotus lividus, which either overexploited $P$. oceanica meadows or smaller and sparser seagrasses such as Cymodocea nodosa, which replaced $P$. oceanica as salinity levels probably dropped (Díaz-Almela and Duarte, 2008; Fernandez et al., 2006). The discrete but clear presence of several brackish taxa such as $C$. torosa $\mathrm{f}$. litoralis, L. elliptica, $N$. crenulata, $H$. acuta, A. tepida and H. germanica (Debenay and Guillou, 2002; Frenzel et al., 2010) and the small numbers of $P$. conicus suggest more brackish conditions with polyhaline to euhaline waters particularly to the upper part of this biophacies. The foraminiferal assemblages resemble the B1 assemblage of Dimiza et al., (2016) which characterises vegetated open lagoon to shallow marine environments. Hence, the environmental conditions that prevail in this biofacies can be characterised as a rather closed protected gulf with shallow waters, with a good connection with the sea though, towards the upper part occasional fresh water supply maintained salinities to polyhaline-euhaline levels. This can be verified by the increasing grain size of the sediments that progressively changes from higher percentages of silt into higher percentages of sand.

The next unit, Unit $4(2.3-1.5 \mathrm{~m})$, is also marked by the total absence of macro- and microfossil remains as in biofacies 2. Again inhospitable conditions for living organisms prevailed, and consequently anoxic conditions were responsible for sediment layers without life. This can be shown with the increase in the percentage of T.O.C. while T.N. values reach zero levels. Probably the area turned again into a closed gulf with no good connection with the sea.

In the upper Unit, Unit $5(1.5-0 \mathrm{~m})$, the significant reduction in the species number is clearly notable in respect to Units 1 and 3. From 91species in Unit 3 the species number drops to 24. The latter indicates that the environmental conditions in the basin changed significantly. The loss of several shallow shelf taxa, and the discrete but not dominant presence of brackish/lagoonal taxa such as $C$. torosa f. litoralis, N. crenulata, H. acuta, A. tepida and $H$. germanica suggests that the closed and protected gulf with shallow waters becomes more closed and its connection to the sea is getting further reduced. The dominance of $B$. reticulatum suggests the presence of shallow water algae (Fishelson, 2000). The foraminiferan taxa A. beccarii, A. tepida, E. crispum and E. macellum, dominate the assemblages as well indicating soft bottom and nutrient rich sediments, nevertheless with low oxygen (Murray, 2006) and being quite similar with the Group B assemblage described by Koukousioura et al. (2012). Two more, smaller scale anoxic events have been observed at 0.4 and $0.8 \mathrm{~m}$, where total absence of subfossil findings occurred. Subsequently, the upper 1.5 meter of the core indicates that the closed gulf, as described above, turned into a normal leaky lagoon (Murray, 2006) where more brackish low oxygen conditions prevailed, basically similar to the present condition of the lagoon.

Conclusively, AG-1 core was divided into 5 sedimentological units based on grain size distribution, geochemistry and macro- and micro fauna assemblages. With radiocarbon dating the age of each sedimentary unit has been estimated and the chronological framework of the present study covers the late Holocene from around 4040 to present.

Based on sedimentological and palaeoecological data it is suggested that from around 4040-3460 \pm 30 yr BP (Unit 1) the study area was represented by a gulf with good connection to the open sea and occasional fresh water supply (Subunit 1A). This environment changes into a closed gulf with no good connection with the sea (Subunit 1B).

From around 3460-740 \pm 30 yr BP (Units 2 and 3) the environment remains a rather closed gulf with shallow waters, with a good connection with the sea and with occasional fresh water supply that maintained salinities to polyhaline-euhaline levels. 
The environment changes again from 740-360 $\pm 30 \mathrm{yr}$ BP (Unit 4) as anoxic conditions prevailed that indicate a closed gulf with no good connection with the sea.

Finally from 360-0 \pm 30 yr BP (Unit 5) palaeoecological data reflect a closed gulf that turned gradually into a normal leaky lagoon (Murray, 2006) where more brackish conditions occurred, similar to the present day condition.

\section{References}

Bakir, B.B., Öztürk1, B., Doğan, A. and Önen, M., 2012. Mollusc Fauna of Iskenderun Bay with a Checklist of the Region, Turkish Journal of Fisheries and Aquatic Sciences, 12, 171-184.

Bird, E., 2008. Coastal geomorphology, An introduction, Chichester, John Wiley and Sons Ltd.

Blott, S.J. and Pye, K., 2004. Morphological and sedimentological changes on an artificially nourished beach, Lincolnshire, UK, Journal of Coastal Research, 20, 214-233.

Bronk Ramsey, C., 2009. Bayesian analysis of radiocarbon dates, Radiocarbon, 51, 337-360.

Candan, O., Çetinkaplan, M., Oberhänsli, R., Rimmelé, G. and Akal, C., 2005. Alpine high-P/low$\mathrm{T}$ metamorphism of the Afyon Zone and implications for the metamorphic evolution of Western Anatolia, Turkey, Lithos, 84, 102-124.

Carroll, M.L., Cochrane, S., Fieler, R., Velvin, R. and White, P., 2003. Organic enrichment of sediments from salmon farming in Norway: environmental factors, management practices, and monitoring techniques, Aquaculture, 226, 165-180.

Debenay, J.P. and Guillou, J.J., 2002. Ecological transitions indicated by foraminiferal assemblages in paralic environments, Estuaries, 25, 1107-1120.

Díaz-Almela, E. and Duarte, C.M., 2008. Management of Natura 2000 habitats. 1120 *Posidonia beds (Posidonion oceanicae), European Commission, 32 pp.

Dimiza, M.D., Koukousioura, O., Triantaphyllou, M.V. and Dermitzakis, M.D., 2016. Live and dead benthic foraminiferal assemblages from coastal environments of the Aegean Sea (Greece): Distribution and diversity, Revue de Micropaléontologie, 59, 19-32.

Fairbanks, R.G., 1989. A 17,000 year glacio-eustatic sea level record: influence of glacial melting rates on the Younger Dryas event and deep-ocean circulation, Nature, 342, 637-642.

Fernández-Torquemada, Y. and Sánchez-Lizaso, J.L., 2005. Effects of salinity on leaf growth and survival of the Mediterranean seagrass Posidonia oceanica (L.) Delile, Journal of Experimental Marine Biology and Ecology, 320, 57-63.

Fernandez, C., Pasqualini, V., Boudouresque, C.F., Johnson, M., Ferrat, L., Caltagirone, A. and Mouillot, D., 2006. Effect of an exceptional rainfall event on the sea urchin (Paracentrotus lividus) stock and seagrass distribution in a Mediterranean coastal lagoon, Estuarine, Coastal and Shelf Science, 68(1-2), 259-270.

Fishelson, L., 2000. Marine animal assemblages along the littoral of the Israeli Mediterranean seashore: The Red-Mediterranean Seas communities of species, Italian Journal of Zoology, 67 (4), 393-415.

Folk, R.L., 1974. Petrology of Sedimentary Rocks, Hemphill Publishing Co, Austin, Texas, 170 pp.

Frenzel, P., Keyser, D. and Viehberg, F., 2010. An illustrated key and (palaeo)ecological primer for Postglacial to Recent Ostracoda (Crustacea) of the Baltic Sea, Boreas, 39(3), 567-575.

Gaudette, H., Flight, W., Toner, L. and Folger, D., 1974. An inexpensive titration method for the determination of organic carbon in recent sediments, Journal of Sedimentary Petrology, 44, 249-253.

Hemminga, M.A. and Duarte, C.M., 2001. Seagrass Ecology, Cambridge University Press, Cambridge, $312 \mathrm{pp}$.

Jones, C.A. and Kaiteris, P., 1983. A Vacuum-Gasometric Technique for Rapid and Precise Analysis of Calcium Carbonate in Sediments and Soils, Journal of Sedimentary Research, 53, 655660 .

Institute of Geology and Mineral Exploration (IGME), 1983, Geological Map of Greece, scale $1: 500000,2^{\text {nd }}$ edition, Athens. 
Kayan, İ., 1999. Holocene stratigraphy and geomorphological evolution of the Aegean coastal plains of Anatolia, Quaternary Science Reviews, 18(4-5), 541-548.

Kjerfve, B., 1994. Coastal lagoon processes, Amsterdam, Elsevier, 576 pp.

Koukousioura, O., Triantaphyllou, M.V., Dimiza, M.D., Pavlopoulos, K., Syrides, G. and Vouvalidis, K., 2012. Benthic foraminiferal evidence and paleoenvironmental evolution of Holocene coastal plains in the Aegean Sea (Greece), Quaternary International, 261, 105-117.

Kovalyova, M., 2015. Morphometric Characteristics of the Shell and Distribution along the Crimean Coast (Black Sea) of Petricola lithophaga (Retzius, 1788) (Mollusca: Veneridae), Acta Zoologica Bulgarica, 67(4), 587-590.

Lambeck, K., 1995. Late Pleistocene and Holocene sea-level change in Greece and south-western Turkey: a separation of eustatic, isostatic andtectonic contributions, Geophysical Journal Iternational, 122, 1022-1044.

Lambeck, K. and Purcell, A., 2005. Sea-level change in the Mediterranean Sea since the LGM: model predictions for tectonically stable areas, Quaternary Science Reviews, 24, 1969-1988.

Marbà, N., Holmer, M., Gacia, E. and Barron, C., 2006: Seagrass Beds and Coastal Biogeochemistry. In: Larkum, A.W.D., Orth, R.J. and Duarte, C.M., eds., Seagrasses: Biology, Ecology and Conservation, Springer, 135-157.

Müller, G. and Gastner, M., 1971. The Karbonat-Bombe a simple device for the determination of the carbonate content in sediments, soils and other materials, N. Jb. Miner. Mh, 10, 466-469.

Murray, J.W., 2006. Ecology and Applications of Benthic Foraminifera, Cambridge University Press, Cambridge, 440 pp.

Perçin-Paçal, F., Altinsaçli, S. and Balkis, H., 2015. An updated checklist of recent marine and coastal brackish water ostracods (Crustacea Ostracoda) in Turkey, Journal of Entomology and Zoology Studies, 3(3), 20-33.

Ring, U., Layer, P.W. and Reischmann, T., 2001. Miocene high-pressure metamorphism in the Cyclades and Crete, Aegean Sea, Greece: evidence for large-magnitude displacement on the Cretan detachment, Geol. Soc. Am., 29, 395-398.

Ring, U., Glodny, J., Will, T. and Thomson, S., 2010. The Hellenic subduction system: highpressure metamorphism, exhumation, normal faulting, and large-scale extension, Аnпи. Rev. Earth Planet. Sci., 38, 45-76.

Senel, M., 2002. Geological map of Turkey: Sheet ÏZÏR (1:500000), General Directorate of Mineral Research and Exploration, Ankara, Turkey.

Schaanning, M.T., 1994. Distribution of sediment properties in coastal areas adjacent to fish farms and environmental evaluation of five locations surveyed in October 1993, Norwegian Institute for Water Research (NIVA), Report No. O-93205, O-93062, Oslo, Norway. 